\title{
Effect of Different Sources and Doses of Nitrogen on
} Vegetative and Productive Performance of Sugarcane under a Dystrophic Red Latosol Condition

\author{
Flávio Henrique Ferreira Gomes ${ }^{1}$, Frederico Antonio Loureiro Soares ${ }^{1}$, Marconi Batista Teixeira ${ }^{1}$, Edson Cabral \\ da Silva ${ }^{1}$, Nelmicio Furtado da Silva ${ }^{1}$, Fernando Nobre Cunha ${ }^{1}$ and Cicero Teixeira Silva Costa ${ }^{2}$ \\ 1. Federal Institute of Education, Science and Technology of Goiás, Rio Verde Campus, Rio Verde 75901-970, GO, Brazil \\ 2. Federal Institute of Education, Science and Technology of Mato Grosso do Sul, Campus Naviraí, Naviraí 79950-000, MS, Brazil
}

\begin{abstract}
The aim of this work was to evaluate the effects of the application of different sources and doses of nitrogen $(\mathrm{N})$ in the growth and productivity of sugarcane in cane plant. Field experiments were conducted in the area of Rio Paraiso II farm, belonging to the Raízen factory, in the city of Jataí, GO. The soil was classified as dystrophic red latosol. The experimental design used was in randomized block, analysed in factorial scheme of $2 \times 4 \times 4$, with three replications. The factors analysed were two sources of $\mathrm{N}$ (urea and ammonium nitrate), four doses of $\mathrm{N}(0,60,120$ and $180 \mathrm{~kg} / \mathrm{ha})$ and four evaluation times $(210,250,290$ and $330 \mathrm{~d}$ after planting (DAP)). The parameters analysed were plant height (PH), diameter of stalks (DS), length of internodes (LI) and productivity of stalks (PS). Results observed significant difference in the sources and doses of $\mathrm{N}$ for the evaluated parameters in sugarcane plant. Urea in the average doses of $110 \mathrm{~kg} / \mathrm{ha}$ and $100.87 \mathrm{~kg} / \mathrm{ha}$ provided the greatest PH and LI of sugarcane, respectively. Ammonium nitrate at a dose of $180 \mathrm{~kg} /$ ha presented the largest DS of sugarcane (cane plant) at 330 DAP. The PS of sugarcane SP80-1816 at 60 $\mathrm{kg} / \mathrm{ha}$ and $120 \mathrm{~kg} / \mathrm{ha}$ ammonium nitrate has higher increments. For the PS, it is recommended the application of doses between 60 $\mathrm{kg} / \mathrm{ha}$ and $120 \mathrm{~kg} / \mathrm{ha}$ of $\mathrm{N}$ of the source ammonium nitrate in sugar cane (cane plant).
\end{abstract}

Key words: Saccharum spp., urea, ammonium nitrate, yield, biometry.

\section{Introduction}

Currently, the sugarcane industry appears to be very favorable, due to the depletion of oil reserves and the high price of oil. In 2015 and 2016, the sugar and alcohol complex accounted for $9.67 \%$ and $13.36 \%$ of the value of all Brazilian agribusiness products, respectively. In 2015, the main buyers of sugar were China, Bangladesh and Algeria, acquiring approximately $2.5,2.46$ and 1.62 million tons, respectively. In the same year, the main buyers of alcohol were the United States, South Korea and China, acquiring approximately 629, 514 and 28 thousand tons of the products [1]. Sugarcane is

\footnotetext{
Corresponding author: Flávio Henrique Ferreira Gomes, postgraduate student, research field: agrarian science-agronomy.
}

currently considered one of the main agricultural commodities [2]. Brazil accounts for $33 \%$ of all sugarcane produced in the world [3].

The sugarcane is considered one of the greatest alternatives to the biofuels sector, due to the great potential in the production of ethanol and their byproducts. The area planted with sugar cane, harvested and destined to the sugar-alcohol activity, in the 2016/2017 harvest, will be approximately 9,110.9 thousand hectares [4].

For there to be sufficient ethanol production to supply, first, the national need and then exporting this fuel, large areas need to be planted with the crop, along with growing technologies that should be adopted to improve productivity. Therefore, adequate management practices, such as irrigation and fertilization should be adopted to achieve such objectives [5]. To keep the 
industry growing on profitable terms, it should be supported by expanding agricultural areas and increasing productivity. Thus, it is of fundamental importance to apply new techniques that aim at optimizing the sector, regarding the technological evolution, in order to provide continuous increase of productivity index by area [6].

The sugarcane grown in Brazil uses the application of lower doses of nitrogen $(\mathrm{N})$ fertilizer than other crop producing countries [7]. The great demand of $\mathrm{N}$ by the crop, the high financial and energetic cost of $\mathrm{N}$ fertilizers, the environmental risks related to the addition of $\mathrm{N}$ mineral in the system and other questions have originated several studies on $\mathrm{N}$ fertilization in sugarcane [7-9]. $\mathrm{N}$ is the most required nutrient in cultivated plants, it is important for plant metabolism, and it is a constituent of enzymes, proteins, DNA, RNA, chlorophylls and precursors of hormones [10]. Thus, it is the nutrient that most limits plant production [11].

$\mathrm{N}$ fertilization stands out as one of the cultural practices with the greatest demand for research and for the sugar cane crop. Special attention is needed, since $\mathrm{N}$ studies present very variable results [12]. The evaluation of biometric variables and productivity has been conducted by various researchers [13-16], in the search for answers to applied treatments, which may allow the improvement of techniques for soil and crop management. In study conducted by Oliveira et al. [17], no effects were observed in their treatments for stalk yield. Although in the work conducted by Megda et al. [18] and Schultz et al. [19], increments were observed in the sugarcane productivity with the application of $\mathrm{N}$ fertilizers.

The objective of this study was to evaluate the effects of the application of different sources and $\mathrm{N}$ rates on the development and productivity of sugarcane (var. SP80-1816) in the cane-plant cycle, cultivated in a dystrophic red latosol.

\section{Materials and Methods}

\subsection{Study Area}

The experiment was conducted under field conditions, in an area of Rio Paraiso II farm, belonging to the Raízen factory, in the municipality of Jataí, GO. The geographical coordinates of the site are $17^{\circ} 43^{\prime} 15.23^{\prime \prime} \mathrm{S}$ and $51^{\circ} 38^{\prime} 12.62^{\prime \prime} \mathrm{W}$, with an average elevation of $912 \mathrm{~m}$. According to the classification of Köppen [20], the climate of the place is of type Aw, tropical, with rainy season in the months of October-April, and drought season in the months of May-September. The maximum temperature ranges from $35{ }^{\circ} \mathrm{C}$ to $37{ }^{\circ} \mathrm{C}$, and the minimum of $12{ }^{\circ} \mathrm{C}$ to $15{ }^{\circ} \mathrm{C}$. The rainfall occurred during the period of the experiment was $1,676.5 \mathrm{~mm}$, according to Fig. 1.

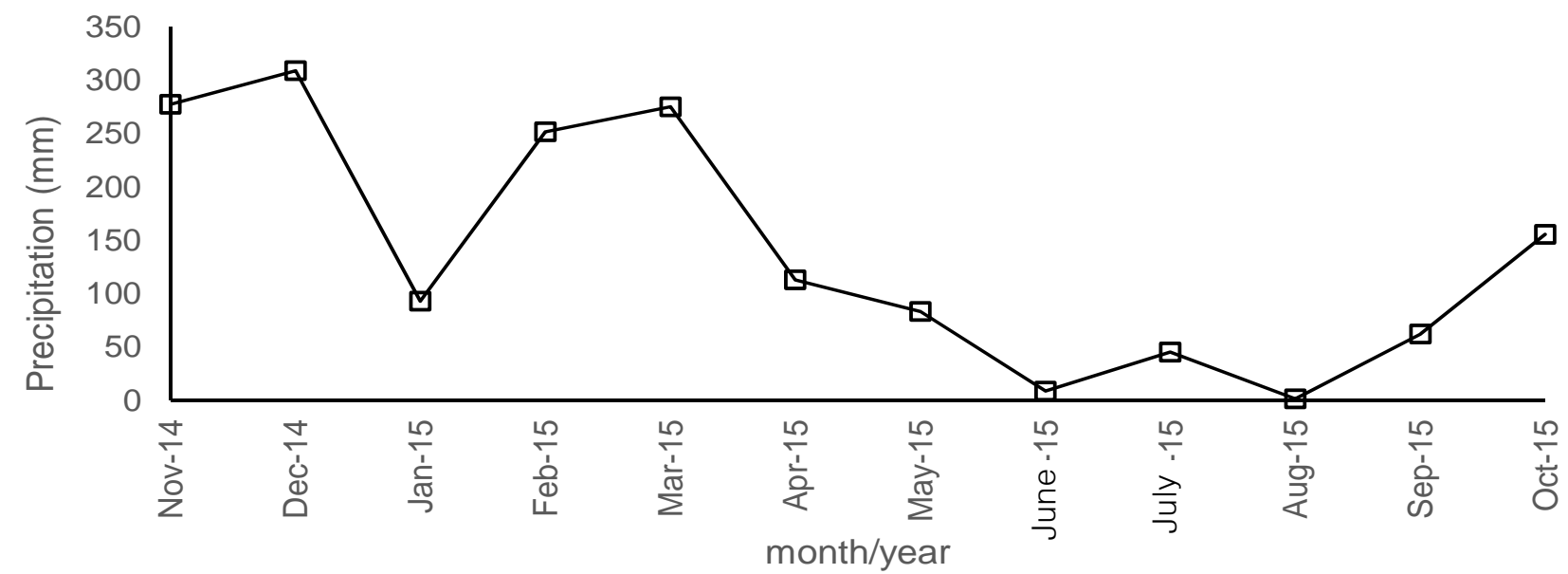

Fig. 1 Rainfall occurred in the municipality of Jataí, GO, during the conduction of the experiment (cane plant, harvest 2014/2015).

Source: INMET normal station, Jataí, GO, Brazil. 


\subsection{Soil Analysis}

The initial soil samples were collected from the layers of $0.00-0.20,0.20-0.40$ and $0.40-0.60 \mathrm{~m}$, for the chemical characterization. The soil of the experimental area was classified as dystrophic red latosol, in a very clayey closed phase [21]. The chemical characteristics of the soil of the experimental area in samples collected before the implantation of the experiments were presented in Table 1.

\subsection{Experiment Design}

The experimental design used was in randomized block, analysed in a factorial scheme of $2 \times 4 \times 4$, with three replications, the factors analysed were two sources of $\mathrm{N}$ (urea and ammonium nitrate), four doses of $\mathrm{N}(0,60,120$ and $180 \mathrm{~kg} / \mathrm{ha})$ and four evaluation times: 210, 250, 290 and $330 \mathrm{~d}$ after planting (DAP).

The sugarcane variety SP80-1816 was developed by the Agronomic Institute of Campinas (IAC), which stood out in the adaptation to the edaphoclimatic conditions of Cerrado. Soil preparation was performed by the conventional system through plowing and harvesting, followed by opening of the planting grooves.

Planting was carried out on November 20th, 2014 in a mechanized manner, according to the experience of the Raízen factory, and the number of buds per meter, according to the recommendations for the respective variety. In the experiment, five lines of sugar cane with $5 \mathrm{~m}$ long constituted the experimental units, spaced $1.50 \mathrm{~m}$ apart. The plot area covered three central lines of each plot, scoring $1 \mathrm{~m}$ at each end.
$\mathrm{N}$ fertilization was applied according to the treatments at 60 DAP. All treatments were fertilized in the planting groove, with phosphorus $\left(\mathrm{P}_{2} \mathrm{O}_{5}\right)$ in the form of triple superphosphate, potassium $\left(\mathrm{K}_{2} \mathrm{O}\right)$ in the form of potassium chloride, and micronutrients, if necessary, according to soil analysis results for an expected yield higher than $120 \mathrm{t} / \mathrm{ha}$ of stalks, according to Sousa and Lobato's recommendations [22].

The cultural treatments related to the use of herbicides, insecticides, fungicides and other products related to the control of weeds, pests and diseases were used according to the need and evaluation of infestation, and according to the experience of the Raízen factory.

The biometric evaluations were performed in two demarcated plants and located in the useful area of each plot at 210, 250, 290 and 330 DAP. The floor area consisted of the central linear meter of the main line of each plot. The analyzed variables were: plant height $(\mathrm{PH})$, measured from the soil to the last completely open leaf ligule; diameter of stalks (DS), measured at the base of the stem with the aid of a digital caliper; length of internodes (LI), measured from one coach to another.

The harvest was performed on October 20th, 2015, and productivity of stalks (PS) (tons per hectare stalks, THS) was determined by weighing the total useful area stems present in the respective plots, and then quantifying the weight of stems present in the two lines of each plot. For this, the cut was made as close as possible to the soil. The stems were broken and the pointer pointed. Then weighed in a hook-type digital scale (accuracy $=0.02 \mathrm{~kg}$ ), with a capacity of $50 \mathrm{~kg}$.

Table 1 Chemical characterization of the soil of the experimental area before the installation of the experiment, Raízen factory, Jataí, GO, Brazil, 2014.

\begin{tabular}{|c|c|c|c|c|c|c|c|c|c|c|c|}
\hline $\begin{array}{l}\text { Soil layer } \\
\text { (m) }\end{array}$ & $\begin{array}{l}\mathrm{pH}^{*} \\
\left(\mathrm{H}_{2} \mathrm{O}\right)\end{array}$ & $\begin{array}{l}\text { OM } \\
(\mathrm{g} / \mathrm{kg})\end{array}$ & $\begin{array}{l}P \\
\left(\mathrm{mg} / \mathrm{dm}^{3}\right)\end{array}$ & K & $\mathrm{Ca}$ & $\mathrm{Mg}$ & $\begin{array}{c}\mathrm{Al} \\
\left(\mathrm{mmol}_{\mathrm{c}} / \mathrm{d}_{1}\right.\end{array}$ & $\begin{array}{l}\mathrm{H}+\mathrm{Al} \\
\left.\mathrm{a}^{3}\right)\end{array}$ & $S$ & CEC & $\begin{array}{l}\mathrm{V} \\
(\%)\end{array}$ \\
\hline $0.00-0.20$ & 5.8 & 76.00 & 20.00 & 1.10 & 28.00 & 14.00 & 0.00 & 20.00 & 43.10 & 63.10 & 68.00 \\
\hline $0.20-0.40$ & 5.9 & 80.00 & 14.00 & 1.00 & 29.00 & 15.00 & 0.00 & 20.00 & 45.00 & 65.00 & 69.00 \\
\hline $0.40-0.60$ & 6.5 & 64.00 & 7.00 & 0.60 & 7.00 & 7.00 & 0.00 & 25.00 & 14.60 & 39.60 & 37.00 \\
\hline
\end{tabular}

pH in distilled water.

OM: organic matter; CEC: cation exchange capacity; V: base saturation. 


\subsection{Statistic Analysis}

The data were submitted to analysis of variance, applying the $F$ test to $5 \%$ probability level. And in case of significance of regression, analysis was performed for $\mathrm{N}$ and time rates, while for $\mathrm{N}$ sources, the means were compared between them by the Tukey test at $5 \%$ of probability, using the statistical program $\operatorname{SISVAR}^{\circledR}[23]$.

\section{Results and Discussion}

There was a significant effect in relation to the $\mathrm{N}$ doses applied to sugarcane for the variables PH, DS and LI. The interaction between the factors source (S) $\times$ dose (D) was significant for all variables analyzed. The periods (DAP) were significant for all variables analyzed. There was a significant effect on the $\mathrm{S} \times$ DAP interaction for DS (Table 2).

The interaction between sources and $\mathrm{N}$ rates in sugarcane was significant $(p<0.01)$ for PS (Table 3 ). Significant $\mathrm{N}$ application results were obtained by Megda et al. [18], Schultz et al. [19] and Bastos et al. [24].

In Fig. 2a, the $\mathrm{N}$ of urea source, at $60 \mathrm{~kg} / \mathrm{ha}$ and 120 $\mathrm{kg} / \mathrm{ha}$ for $\mathrm{PH}$, was $4.35 \%$ and $7.35 \%$ higher than compared to the ammonium nitrate source, respectively. However, the ammonium nitrate source at the dose of $180 \mathrm{~kg} / \mathrm{ha}$ of $\mathrm{N}$ for $\mathrm{PH}$ was $5.33 \%$ higher

Table 2 Summary of variance analysis for the variables PH, DS and LI of the sugarcane crop (var. SP80-1816) submitted to different sources and $\mathbf{N}$ doses at different evaluation times, municipality of Jataí, GO, Brazil, 2014/2015 harvest.

\begin{tabular}{lllll}
\hline \multirow{2}{*}{ Sources of variation } & \multirow{2}{*}{ Degrees of freedom } & \multicolumn{3}{c}{ Mean square value for the sources of variation } \\
\cline { 3 - 4 } & & PH & DS & $2.3785^{\text {ns }}$ \\
\hline Sources (S) & 1 & $0.11711^{\text {ns }}$ & $3.4420^{\text {ns }}$ & $6.3141^{*}$ \\
Blocks & 2 & $0.53137^{\text {ns }}$ & $7.8835^{\text {ns }}$ & 0.1216 \\
Residue (a) & 2 & 0.07386 & 5.7119 & $3.2330^{* *}$ \\
Doses (D) & 3 & $0.48466^{* *}$ & $46.2043^{* *}$ & $2.0153^{* *}$ \\
Sources $\times$ doses & 3 & $0.13905^{* *}$ & $7.5777^{*}$ & 0.0827 \\
Residue (b) & 6 & $0.01177^{* *}$ & 1.0877 & $0.9585^{* *}$ \\
Periods (DAP) & 3 & $16.64220^{* *}$ & $60.0790^{* *}$ & $0.0747^{\text {ns }}$ \\
Interaction S $\times$ DAP & 3 & $0.05252^{\text {ns }}$ & $2.4061^{*}$ & $0.0740^{\text {ns }}$ \\
Interaction D $\times$ DAP & 9 & $0.03907^{\text {ns }}$ & $1.0752^{\text {ns }}$ & 0.1357 \\
Interaction S $\times$ D $\times$ DAP & 9 & $0.01720^{\text {ns }}$ & $1.1369^{\text {ns }}$ & 4.59 \\
Residue (c) & 54 & 0.02485 & 0.8073 & 3.79 \\
CV (a) & & 10.32 & 8.57 & 4.85 \\
CV (b) & 4.12 & 3.74 & 3.22 & \\
CV (c) & 5.99 & &
\end{tabular}

${ }^{\mathrm{i}}$ Coefficient of variation $(\mathrm{CV}) ;{ }^{\text {ns }}$ not significant by the $5 \%$ probability $F$ test.

** and ${ }^{*}$ significant at $1 \%$ and $5 \%$ probability, respectively.

Table 3 Summary of variance analysis for sugar cane crop variance (SP80-1816), submitted to different sources and doses of N, municipality of Jataí, GO, Brazil, 2014/2015 harvest.

\begin{tabular}{lll}
\hline Source of variation & Degrees of freedom & Mean square value for the source of variation \\
\hline Sources (S) & 1 & $794.1901^{\text {i }}$ \\
Doses (D) & 3 & $7,545.4296^{* *}$ \\
Sources $\times$ doses & 3 & $134.4442^{* *}$ \\
Blocks & 2 & $5.9269^{*}$ \\
Residue (a) & 14 & 17.2993 \\
CV (a) & & 3.68 \\
\hline
\end{tabular}

${ }^{\mathrm{i}}$ Coefficient of variation $(\mathrm{CV}) ;{ }^{\mathrm{ns}}$ not significant by the $5 \%$ probability $F$ test.

** and ${ }^{*}$ significant at $1 \%$ and $5 \%$ probability, respectively. 
than the source of urea. Marcelo [25] observed a significant effect only for doses in the variable length of sugarcane stalks, with a mean stalk length of 1.32 $\mathrm{m}$ with a dose of $160 \mathrm{~kg} / \mathrm{ha}$ of $\mathrm{N}$. Mendonça et al. [26] found that the doses 64,80 and $96 \mathrm{~kg} / \mathrm{ha}$ of $\mathrm{N}$ provided the same effect on the growth of cultivars, regardless of whether bio-fertilizer or urea was used. Goes et al. [27] studying sources and nitrogen levels in maize crop, did not observe a statistical difference for $\mathrm{PH}$ depending on the sources applied (urea, ammonium sulfate and ammonium nitrate).

In Fig. 2b, in the unfolding of the effects of $\mathrm{N}$ doses within the different $\mathrm{N}$ sources, it was found that for the variable $\mathrm{PH}$, there was an effect for ammonium nitrate and urea sources. According to the linear regression equation obtained for the ammonium nitrate source, a maximum $\mathrm{PH}$ of $1.39 \mathrm{~m}$ was estimated with a dose of $180 \mathrm{~kg} / \mathrm{ha}$ of $\mathrm{N}$; and according to the quadratic regression equation obtained for urea source, a maximum PH of $1.40 \mathrm{~m}$ was estimated with a dose of $110 \mathrm{~kg} / \mathrm{ha}$ of $\mathrm{N}$. For Gírio et al. [28], the addition of $\mathrm{N}(50 \mathrm{~kg} / \mathrm{ha})$ promoted increasing gains up to $180 \mathrm{~d}$, considering the sum of heights, diameters, root dry mass, stem dry mass, shoot dry matter and total dry mass. Cunha et al. [29] observed that for $\mathrm{PH}$ in relation to $\mathrm{N}$ fertigation,

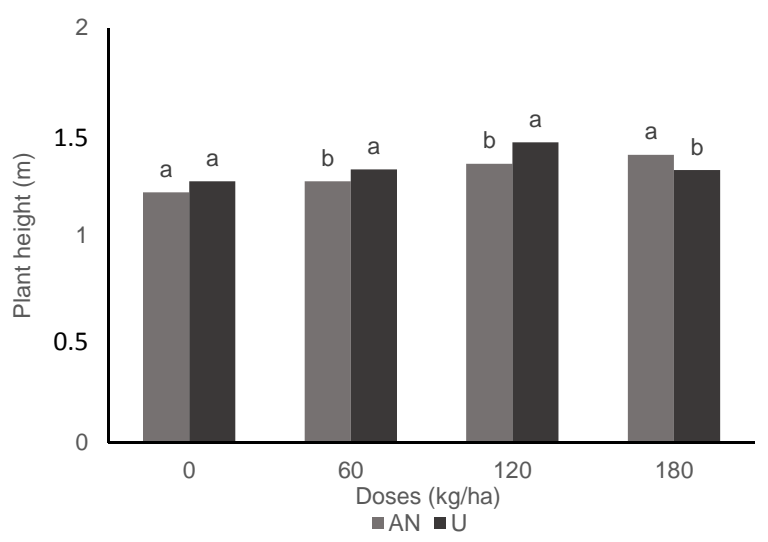

(a) the difference was significant only among 270,300 and $330 \mathrm{~d}$ after the cut, showing increments of $5.8 \%$, $4.3 \%$ and $4.8 \%$, respectively. Oliveira et al. [17] observed significant effects of $\mathrm{N}$ in relation to $\mathrm{PH}$ at 300 DAP and 330 DAP, where it obtained $2.84 \mathrm{~m}$ and $3.12 \mathrm{~m}$, respectively.

Fig. 3a showed that the source of ammonium nitrate at a dose of $180 \mathrm{~kg} / \mathrm{ha}$ of $\mathrm{N}$, for DS, was $5.88 \%$ higher than the urea source. Marcelo [25] did not observe significant effect at doses, sources and interaction between sources $\times$ doses for DS.

In Fig. 3b, in the unfolding of the effects of $\mathrm{N}$ doses, for levels of $\mathrm{N}$ sources, it is possible to verify that for the variable DS, there was an effect for ammonium nitrate and urea sources. According to the linear regression equation obtained for the ammonium nitrate source, a maximum DS of $29.60 \mathrm{~mm}$ was estimated with a dose of $180 \mathrm{~kg} / \mathrm{ha}$ of $\mathrm{N}$; and according to the equation of quadratic regression obtained for urea, the maximum DS of $28.94 \mathrm{~mm}$ was estimated with a dose of $118.46 \mathrm{~kg} / \mathrm{ha}$ of $\mathrm{N}$. In experiments carried out by Silva et al. [30], the mean DS obtained in the experiment was $23 \mathrm{~mm}$, the lowest $21.6 \mathrm{~mm}(1,065$ $\mathrm{mm}$ precipitation and $68 \mathrm{~kg}$ of coverage $\mathrm{N}$ per hectare) and the highest $24.4 \mathrm{~mm}$ (precipitation of $775 \mathrm{~mm}$ and $156 \mathrm{~kg}$ of coverage $\mathrm{N}$ per hectare).

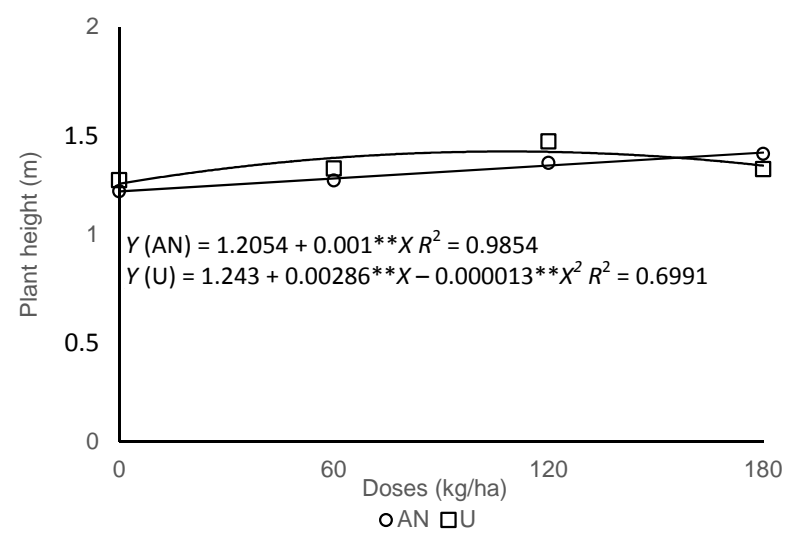

(b)

Fig. 2 PH of sugarcane (var. SP 80-1816), in the cane-plant cycle, as a function of $\mathbf{N}$ sources (a) and $\mathbf{N}$ doses (b), municipality of Jataí, GO, Brazil, 2014/2015 harvest.

Means followed by the same letter do not differ significantly by the Tukey test at $5 \%$ probability.

${ }^{* *}$ Significant at $1 \%$ probability by the $F$ test.

$\mathrm{U}$ : urea source; AN: ammonium nitrate source. 
A statistical difference was observed between the sources of $\mathrm{N}$ for $\mathrm{DS}$ at 330 DAP, where the ammonium nitrate source was $4.17 \%$ superior to the source urea (Fig. 3c).

In Fig. 3d, in the unfolding of the effects of DAP for the levels of $\mathrm{N}$ sources, it can be seen that for the DS variable, there was an effect for ammonium nitrate and urea sources. According to the linear regression equations obtained for ammonium nitrate and urea sources, the maximum DS of $30.24 \mathrm{~mm}$ and 29.16 $\mathrm{mm}$ were estimated at 330 DAP. Tavares \& Zonta [31] observed that in the analysis of DS evolution, accelerated diameter growth at the beginning of the crop cycle occurred between 163 DAP and 232 DAP, a slight growth between 232 DAP and 296 DAP for

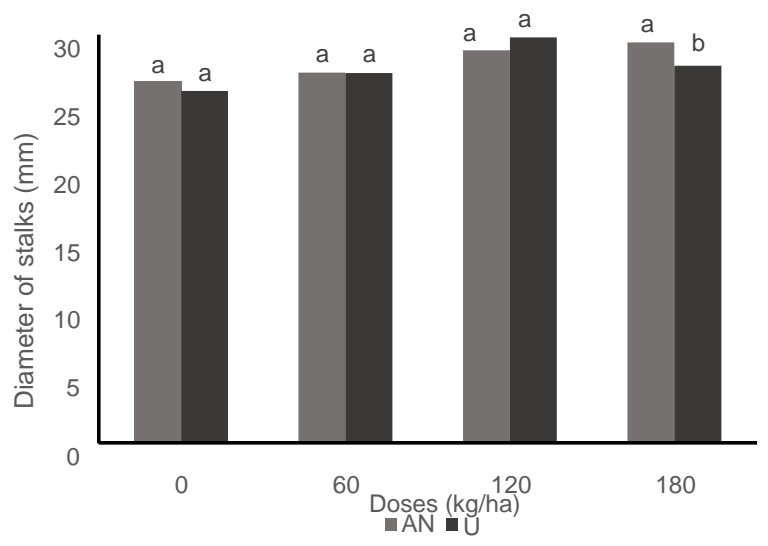

(a)

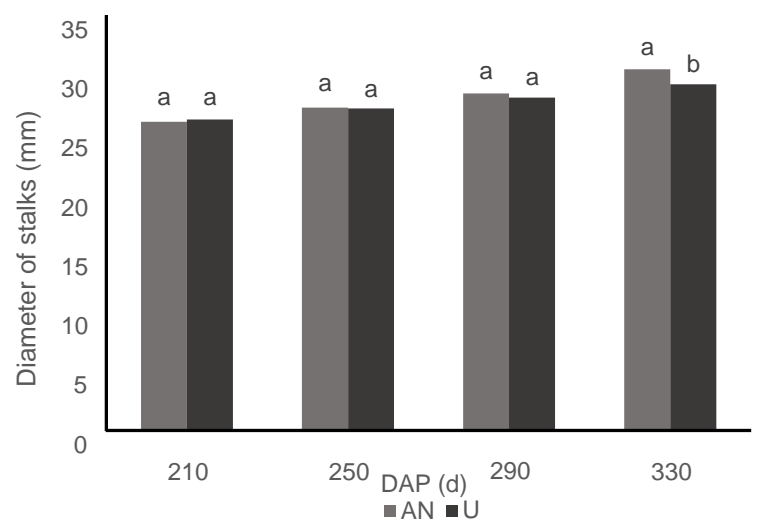

(c) all treatments. Afterwards, there is a slight fall, between 357 DAP and 426 DAP. Silva et al. [15], working with irrigated cane, found that the largest DS was $37.9 \mathrm{~mm}$, obtained at 330 DAP. Oliveira et al. [17], applying $100 \mathrm{~kg} / \mathrm{ha}$ of urea to cane plant, observed significant effects for DS from 150 DAP to 330 DAP, obtaining a DS of $35.58 \mathrm{~mm}$ at 330 DAP.

Fig. 4a showed that urea source, at $60 \mathrm{~kg} / \mathrm{ha}$ and $120 \mathrm{~kg} / \mathrm{ha}$ of $\mathrm{N}$ for LI, was $6.94 \%$ and $11.32 \%$ higher at ammonium nitrate source, respectively. The ammonium nitrate source at the dose of $180 \mathrm{~kg} / \mathrm{ha}$ of $\mathrm{N}$ to $\mathrm{LI}$ was $5.09 \%$ higher than the urea source. In studies carried out by Vale et al. [32], $\mathrm{N}$ and $\mathrm{P}$ were the nutrients that most limited the growth of sugarcane plants, with reductions of $91 \%$ and $57 \%$, respectively.

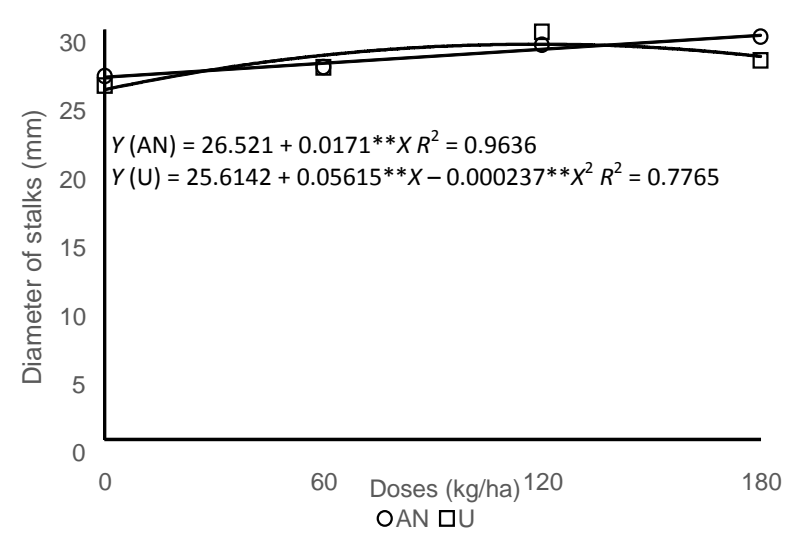

(b)

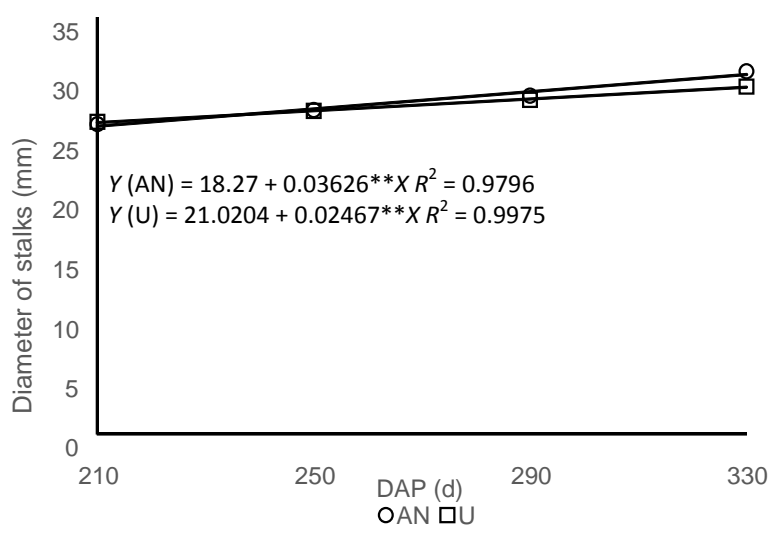

(d)

Fig. 3 Sugarcane DS (SP 80-1816) in the cane plant cycle, as a function of $N$ (a) and sources (c), $N$ (b) and times (d), municipality of Jataí, GO, Brazil, 2014/2015 harvest.

Means followed by the same letter do not differ significantly by the Tukey test at $5 \%$ probability.

${ }^{* *}$ Significant at $1 \%$ probability by the $F$ test.

$\mathrm{U}$ : urea source, AN: ammonium nitrate source. 
In Fig. 4b, in the unfolding of the effects of the $\mathrm{N}$ doses for the $\mathrm{N}$ sources, it can be seen that for the LI variable, there was a significant effect for ammonium nitrate and urea sources. According to the linear regression equation obtained for the ammonium nitrate source, the maximum LI of $7.85 \mathrm{~cm}$ was estimated with the dose of $180 \mathrm{~kg} / \mathrm{ha}$ of N. According to the quadratic regression equation obtained for the urea source, the estimated maximum LI was $8.28 \mathrm{~cm}$ with the dose of $100.87 \mathrm{~kg} / \mathrm{ha}$ of $\mathrm{N}$. Penkowski et al. [33], studying doses of $\mathrm{N}$ in wheat, found that the doses did not influence LI. Cunha et al. [16] observed that LI increased by $6.4 \%$ every $80 \mathrm{~d}$, totaling $19.3 \%$ between 90 DAP and 330 DAP. Silva et al. [34] found isolated effects on their treatments, and at 330 DAP, they observed an LI of approximately $16 \mathrm{~cm}$.

Fig. 5a showed that the ammonium nitrate source at $60 \mathrm{~kg} / \mathrm{ha}$ and $120 \mathrm{~kg} / \mathrm{ha}$ of $\mathrm{N}$ for PS was $17.83 \%$ and $15.21 \%$ higher than the source of urea, respectively. In studies conducted by Megda et al. [18], the PS was positively influenced by the $\mathrm{N}$ fertilization by the ammonium chloride, ammonium sulfate and urea sources, respectively, producing 101.5, 106.1 and 105 $\mathrm{t} / \mathrm{ha}$, while the ammonium nitrate did not differ from the control treatment. Amaral and Molin [35], using the ammonium nitrate source at doses of 50, 100, 150

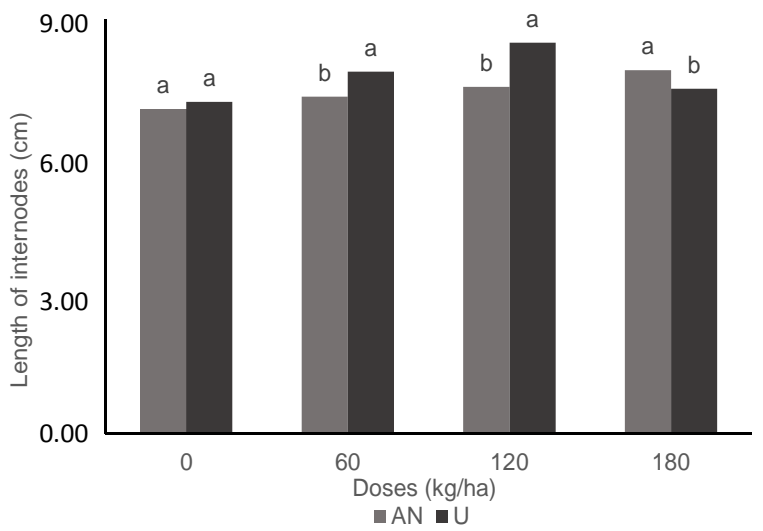

(a) and $200 \mathrm{~kg} / \mathrm{ha}$, obtained a mean PS of $101 \mathrm{t} / \mathrm{ha}$, while in the control treatment a mean PS of $90.4 \mathrm{t} / \mathrm{ha}$.

In the unfolding of the effects of the doses of $\mathrm{N}$, within the different sources of $\mathrm{N}$, it is possible to verify that for PS variable, there was an effect for ammonium nitrate and urea sources (Fig. 5b). According to the linear regression equation obtained for the ammonium nitrate and urea sources, a maximum PS of $158.69 \mathrm{t} / \mathrm{ha}$ and $149.28 \mathrm{t} / \mathrm{ha}$ was estimated with a dose of $180 \mathrm{~kg} / \mathrm{ha}$ of $\mathrm{N}$.

Schultz et al. [19], applying a dose of $120 \mathrm{~kg} / \mathrm{ha}$ of $\mathrm{N}$ as urea in cane plant, obtained PS of $177.7 \mathrm{t} / \mathrm{ha}$ for variety RB72454 and 157.2 t/ha for variety RB867515. Bastos et al. [24] observed a significant effect on the application of $\mathrm{N}$ in the form of urea at a dose of 100 $\mathrm{kg} / \mathrm{ha}$ and obtained a mean PS of $197.06 \mathrm{t} / \mathrm{ha}$, being higher than $17.85 \mathrm{t} /$ ha to treatments where the application of $\mathrm{N}$ did not occur. Oliveira et al. [17], submitting plant cane to treatments with and without $\mathrm{N}$, did not find a significant effect for PS.

In studies conducted by Vitti et al. [14], it was verified that plant cane recovered $30.3 \pm 3.7 \%, 13.9 \pm$ $4.5 \%$ and $6.4 \pm 0.9 \%$ of ${ }^{15} \mathrm{~N}$-urea, ${ }^{15} \mathrm{~N}$-straw and ${ }^{15} \mathrm{~N}$-root system, respectively. Costa et al. [36] concluded that the nitrogenous sources urea and urea + ammonium sulphate presented high losses of $\mathrm{N}-\mathrm{NH}_{3}$

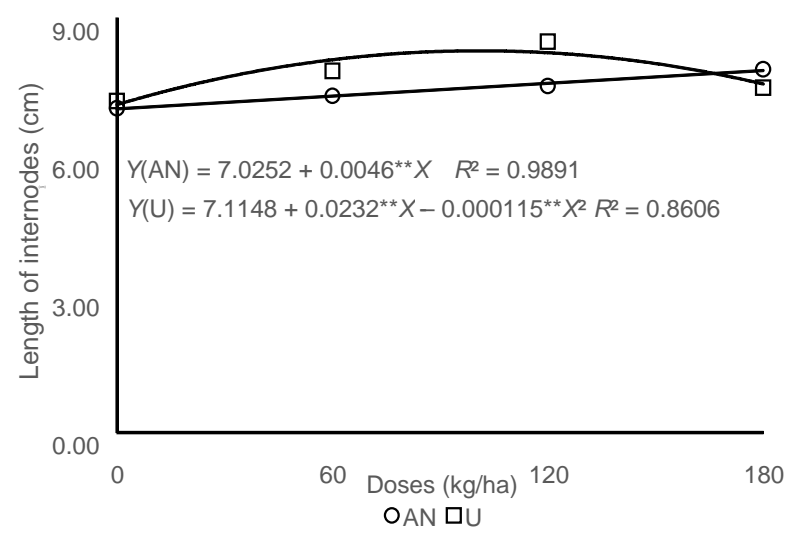

(b)

Fig. 4 LI of sugarcane (var. SP 80-1816), in the cane plant cycle, as a function of $\mathrm{N}$ sources (a) and $\mathrm{N}$ doses (b), municipality of Jataí, GO , Brazil, 2014/2015 harvest.

Means followed by the same letter do not differ significantly by the Tukey test at $5 \%$ probability.

${ }^{* *}$ Significant at $1 \%$ probability by the $F$ test.

$\mathrm{U}$ : urea source; AN: ammonium nitrate source. 


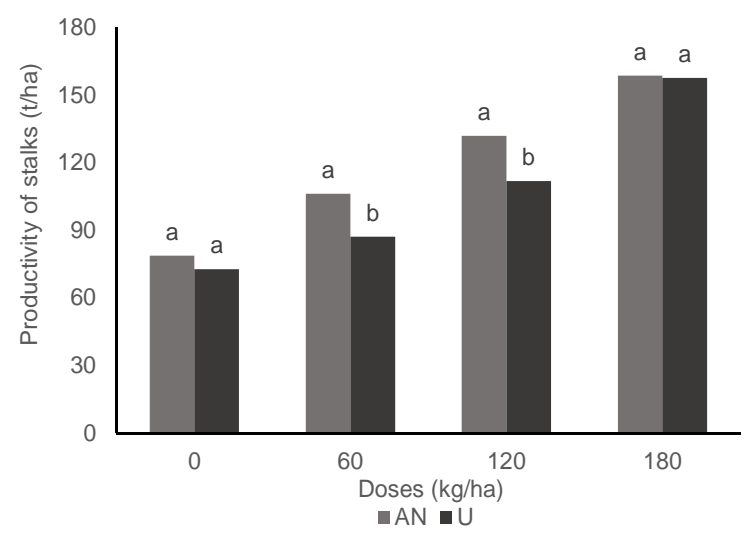

(a)

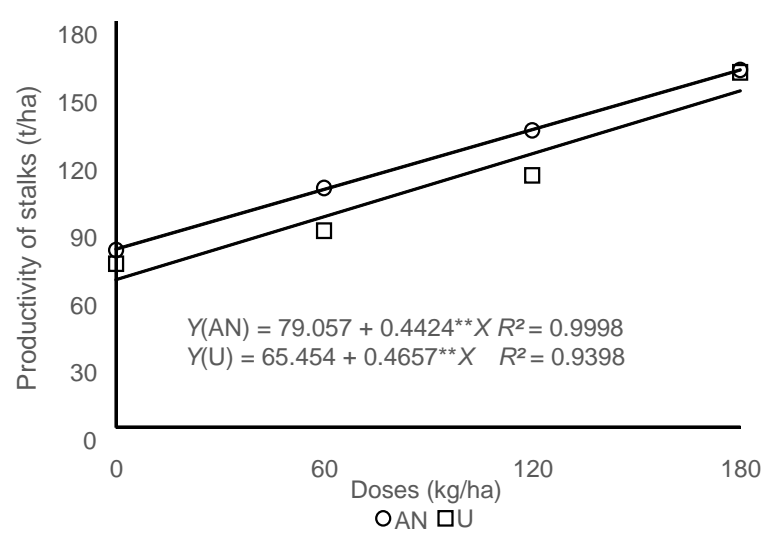

(b)

Fig. 5 PS of sugarcane (var. SP $80+1816$ ), in the cane plant cycle, as a function of $\mathbf{N}$ sources (a) and $\mathbf{N}$ doses (b), municipality of Jataí, GO, Brazil, 2014/2015 harvest.

Means followed by the same letter do not differ significantly by the Tukey test at $5 \%$ probability.

${ }^{* *}$ Significant at $1 \%$ probability by the $F$ test.

U: urea source; AN: ammonium nitrate source.

by volatilization and also, yield of lower sugarcane, in relation to other sources studied.

The non-observance of statistical difference between the sources of $\mathrm{N}$ in the dose of $180 \mathrm{~kg} / \mathrm{ha}$ of $\mathrm{N}$ for the PS may have occurred, because in this dose there is enough $\mathrm{N}$ to supply the need of the plant. The superiority of ammonium nitrate in relation to urea at $60 \mathrm{~kg} / \mathrm{ha}$ and $120 \mathrm{~kg} / \mathrm{ha}$ of $\mathrm{N}$ in relation to PS may have occurred due to the volatilization of ammonia from the urea source, which undergoes the action of the enzyme urease. Urease is found in microorganisms and exerts a unique catalytic function, which is the hydrolysis of urea, producing ammonia and carbonic acid [37].

\section{Conclusions}

The sources of urea and ammonium nitrate are excellent fertilizers, but for the development of the sugarcane, it was not possible to determine the best source and dose. For the PS, it is recommended the application of doses between $60 \mathrm{~kg} / \mathrm{ha}$ and $120 \mathrm{~kg} / \mathrm{ha}$ of $\mathrm{N}$ of the source ammonium nitrate in sugar cane (cane plant).

\section{Acknowledgments}

The authors would like to thank the Ministry of
Science and Technology (MCTIC), the Foundation for Research Support of the State of Goiás (FAPEG), the Brazilian Council for Scientific and Technological Development (CNPq) and Goiano Federal Institute (IF Goiano) for the financial assistance to this research project.

\section{References}

[1] Ministry of Agriculture, Livestock and Food Supply. "Statistics of Foreign Trade of the Brazilian Agribusiness." Accessed July 27, 2017. http://indicadores.agricultura.gov.br/agrostat/index.htm. (in Portuguese)

[2] Devos, K. M. 2010. "Grass Genome Organization and Evolution.” Curr. Opin. Plant Biol. 13 (2): 139-45.

[3] Jadoski, C. J., Toppa, B. E. V., Julianetti, A., Hulsbof, T., Ono, E. O., and Rodrigues, J. D. 2010. "Physiology of the Development of the Vegetative Stage of Sugarcane." Pesquisa aplicada e agrotecnologia 3 (2): 15. (in Portuguese)

[4] National Supply Company (NSC). 2017. "Follow-Up of the Brazilian Sugarcane Harvest 2016/2017." Accessed March 12, 2017. http://www.conab.gov.br/OlalaCMS/ uploads/arquivos/16_12_27_16_30_01_boletim_cana_po rtugues_-3o_lev_-_16-17.pdf. (in Portuguese)

[5] Lelis Neto, J. A. 2012. "The Effect of Vinasse Application by Subsurface Drip Irrigation on Ion Distribution Profile and Physical and Chemical Attributes in Nitosol Soil." Ph.D. thesis, School of Agriculture "Luiz de Queiroz", Piracicaba, 138. (in 
Portuguese)

[6] Silva, N. F. 2014. "Cultivation of Sugarcane under Different Irrigation and Nitrogen Fertigation by Subsurface Drip." M.Sc. thesis, Institute Federal of Education, Science and Technology Goiano Campus Rio Verde, Goiás. (in Portuguese)

[7] Cantarella, H., Trivelin, P. C. O., and Vitti, A. C. 2007. "Nitrogen and Sulfur in Sugarcane Crops." In Nitrogen and Sulfur in Brazilian Agriculture, edited by Yamada, T., Abdalla, S. R. S., and Vitti, G. C. Piracicaba: IPNI Brazil, 355-412. (in Portuguese)

[8] Rossetto, R., Dias, F. L. F., Landell, M. G. A., Cantarella, H., Tavares, S., Vitti, A. C., and Perecin, D. 2010. "N and K Fertilization of Sugarcane Ratoons Harvested without Burning." In Proceeding of International Sugar Cane Technologists Congress. Vera Cruz: ISSCT, 1-8.

[9] Penatti, C. P. 2013. Sugarcane Fertilization-30 Years of Experience. 1st ed.. Itu, SP, Brazil: Editora Ottoni, 347. (in Portuguese)

[10] Barbosa, J. Z., Consalter, R., and Motta, A. C. V. 2012. "Biological Fixation of Nitrogen in Poaceae." Evidência 12 (1): 7-18. (in Portuguese)

[11] Malavolta, E., and Moraes, M. F. 2007. "Fundamentals of Nitrogen and Sulfur in Mineral Nutrition of Cultivated Plants." In Nitrogen and Sulfur in Brazilian Agriculture, edited by Yamada, T., Abdalla, S. R. S., and Vitti, G. C. Piracicaba: IPNI Brazil. (in Portuguese)

[12] Korndörfer, G. H., Colombo, C., Chimello, M. A., and Leone, P. L. C. 2002. "Performance of Sugarcane Varieties Grown with and without Nitrogen." STAB-Açúcar, Álcool e Sub-Produtos 20: 28-31. (in Portuguese)

[13] Hernandes, A., Buzetti, S., Andreotti, M., Arf, O., and Sá, M. E. 2010. "Doses, Sources and Periods of Nitrogen Application in Rice Cultivars." Ciência e Agrotecnologia 34 (2): 307-12. (in Portuguese)

[14] Vitti, A. C., Franco, H. C. J., Trivelin, P. C. O., Ferreira, D. A., Otto, R., Fortes, C., and Faroni, C. E. 2011. "Nitrogen Derived from Fertilization and Straw for Plant Cane Nutrition." Pesquisa Agropecuária Brasileira 46 (3): 287-93. (in Portuguese)

[15] Silva, N. F., Cunha, F. N., Oliveira, R. C., Moura, L. M. F., Moura, L. C., and Teixeira, M. B. 2014. "Analysis of Growth of the Sugarcane under Nitrogen Application by Subsurface Trickle." Revista Brasileira de Agricultura Irrigada 8 (1): 1-11. (in Portuguese)

[16] Cunha, F. N., Silva, N. F., Teixeira, M. B., Morais, W. A., Vidal, V. M., Cunha, E. S., Gomes, F. H. F., and Araújo, A. O. 2016. "Agronomic Performance and Industrial Yield of Sugarcane under Water-Saving Irrigation in Cerrado Soil." African Journal of Agricultural Research 11 (32): 3056-64.
[17] Oliveira, R. C., Silva, N. F., Cunha, F. N., Teixeira, M. B., Soares, F. A. L., and Campos, M. D. 2016. "Effect of Water Replacement and Nitrogen Fertilization on Productivity Variables of Sugar Cane.” African Journal of Agricultural Research 11 (8): 633-43.

[18] Megda, M. X. V., Trivelin, P. C. O., Franco, H. C. J., Otto, R., and Vitti, A. C. 2012. "Agronomic Efficiency of Nitrogen Fertilizers on Green Harvesting Sugarcane Ratoon." Pesquisa Agropecuária Brasileira 47 (12): 1681-90. (in Portuguese)

[19] Schultz, N., Morais, R. F., Da Silva, J. A., Baptista, R. B., Oliveira, R. P., Leite, J. M., Pereira, W., De Barros Carneiro Júnior, J., Alves, B. J. R., Baldani, J. I., Boddey, R. M., Urquiaga, S., and Reis, V. M. 2012. "Agronomic Evaluation of Varieties of Sugar Cane Inoculated with Diazotrophic Bacteria and Fertilized with Nitrogen." Pesquisa Agropecuária Brasileira 47 (2): 261-8. (in Portuguese)

[20] Köppen, W. Köppen Climate Classification System. Accessed May 10, 2016. http:/geography.about.com/ library/weekly/aa011700b.htm.

[21] Brazilian Agricultural Research Company. 2013. Brazilian Soil Classification System. 3rd ed.. Rio de Janeiro: National Soil Research Center, 353. (in Portuguese)

[22] Sousa, D. M. G., and Lobato, E., eds. 2004. Cerrado: Soil Correction and Fertilization. 2nd ed.. Brasília: EMBRAPA Information Technology/EMBRAPA-CPA, 416. (in Portuguese)

[23] Ferreira, D. F. 2011. "Sisvar: A Computer Statistical Analysis System." Ciência e Agrotecnologia 35 (6): 1039-42. (in Portuguese)

[24] Bastos, A. V. S., Oliveira, R. C., Silva, N. F., Teixeira, M. B., Soares, F. A. L., and Silva, E. C. 2015. "Productivity and Dry Matter Accumulation of Sugarcane Crop under Irrigation and Nitrogen Application at Rio Verde, GO, Brazil.” American Journal of Plant Sciences 6: 2374-84.

[25] Marcelo, D. N. 2008. "Effects of Sources and of Nitrogen in Sugarcane Ratoon, Cultivar SP79-1011.” M.Sc. thesis, Federal University of Lavras, Lavras, 44. (in Portuguese)

[26] Mendonça, H. V., Ometto, J. P. H. B., Rocha, W. S. D., Martins, C. E., Otenio, M. H., and Borges, C. A. V. 2016. "Sugarcane Growth with Cattle Biofertilizer and Urea." Revista em Agronegócios e Meio Ambiente 9 (4): 973-87. (in Portuguese)

[27] Goes, R. J., Rodrigues, R. A. F., Takasu, A. T., and Arf, R. 2014. "Sources and Nitrogen Rates on Sidedress to Maize Crop in Reduced Rows Spacing." Revista Agrarian 7 (24): 257-63. (in Portuguese)

[28] Gírio, L. A. S., Dias, F. L. F., Reis, V. M., Urquiaga, S., Schultz, N., Bolonhezi, D., and Mutton, M. A. 2015. "Plant Growth-Promoting Bacteria and Nitrogen 
Fertilization Effect on the Initial Growth of Sugarcane from Pre-sprouted Seedlings." Pesquisa Agropecuária Brasileira 50 (1): 33-43. (in Portuguese)

[29] Cunha, F. N., Silva, N. F., Sousa, A. E. C., Teixeira, M. B., Soares, F. A. L., and Vidal, V. M. 2016. "Yield of Sugarcane Submitted to Nitrogen Fertilization and Water Depths by Subsurface Drip Irrigation.” Revista Brasileira de Engenharia Agrícola e Ambiental 20 (9): 841-6.

[30] Da Silva, C. T. S., De Azevedo, H. M., De Azevedo, C. A. V., Jose, D. N., Carvalho, C. M., and Gomes Filho, R. R. 2009. "Growth of Sugar Cane with and without Irrigation Additional under Different Levels of Coverage Fertilization of Nitrogen and Potassium." Revista Brasileira de Agricultura Irrigada 3 (1): 3-12. (in Portuguese)

[31] Tavares, O. C. H., Lima, E., and Zonta, E. 2010. "Sugarcane Growth and Productivity under Different Tillage and Crop Systems.” Acta Scientiarum. Agronomy 32 (1): 61-8. (in Portuguese)

[32] Vale, D. W., Prado, R. M., Avalhães, C. C., and Hojo, R. H. 2011. "Macronutrients Omission in the Nutrition and Growth of Sugarcane Grown in Nutritious Solution."
Revista Brasileira de Ciências Agrárias 6 (2): 189-96. (in Portuguese)

[33] Penckowski, L. H., Zagonel, J., and Fernandes, E. C. 2009. "Nitrogen and Growth Reducer in High Yield Wheat." Acta Scientiarum. Agronomy 31 (3): 473-9. (in Portuguese)

[34] Silva, N. F., Cunha, F. N., Teixeira, M. B., Soares, F. A. L., Santos, C. C., Filho Cabral, F. R., Silva, E. C., and Morais, W. A. 2016. "Sugarcane Cultivation Submitted to Water Replacement via Irrigation Bar." African Journal of Agricultural Research 11 (32): 2983-93.

[35] Amaral, L. R., and Molin, J. P. 2011. "Optical Sensor to Support Nitrogen Fertilization Recommendation for Sugarcane Crops." Pesquisa Agropecuária Brasileira 46 (12): 1633-42. (in Portuguese)

[36] Costa, M. C. G., Vitti, G. C., and Cantarella, H. 2003. "N-NH ${ }_{3}$ Losses from Nitrogen Sources Applied over Unburned Sugarcane Straw." Revista Brasileira de Ciência do Solo 27 (4): 631-7. (in Portuguese)

[37] Krajewska, B. 2009. "Ureases I. Functional, Catalyctic and Kinetic Properties: A Review." Journal of Molecular Catalysis B: Enzymatic 59 (1-3): 9-21. 